\title{
Historical Analysis of Bauddha Stupa, Kassap Buddha and Shringa Rishi
}

By Dhakal, Devraj

Mr. Dhakal is PhD Scholar from Lumbini Boudha University. Contact at devraj.dhakal1960@, gmail.com

\begin{abstract}
The historical Analysis of Baudha Stupa and Kassap Buddha is the study of the history of Baudha stupa of Baudha Kathmandu Nepal. The main objective of the study is to analyze the historical importance of Boudhanath Stupa and Kasyap Buddha. Comparative Historical Analysis (CHA) method has been applied to analyze the collected facts and information. The story of Nalanika (Nalanika Jatak Katha) claims that Shringa (Having a horn in head) sage was the grandson of Kassap and son of Vibhandak sages was born in Mahalaxmi municipality, Lankuri Bhanjyang Shringa Rishi Ashram. Therefore, Kassap Buddha had visited and settled few times in the municipality. Thus Baudha Stupa - made by relics of Kassap Budha-Baudha Kathmandu has clear relation with Shringa Rishi Ashram of Lalitpur.
\end{abstract}

Keywords: Baudhanath, Kassap Buddha, Shringa Rishi

\section{Background}

Rishya Shringa the Grandson of Kassap Buddha and son of sage Bibhandak was also a famous sage Bodhisattaw of the time. At this time penance of sage Shringa, Sakka -king of heaven was frightened and to break penance of the sage he had sent a nymph(Urbashi) or princess of the kingdom, in Shringa Rishi's Ashram. The nymph/ princess was called as Nalanika. She had very long discussion with Risya Sringa about love, relation and importance of family. The discussion is called Nalanika Jatak in Buddhist philosophy. But Shringa Rishi was very strong in his values and ideologies. She was not able to break his penance so in Buddha's age, she became Yasodhara -Spouse of Lord Buddha. The story has justified the proverb "The facts never fade out". Therefore, Lakuri Bhanjyang is equally important for both Hindu and Buddhist all over the world. India has claimed the place is in India but now it is proved that the birth place of Rishi Shringa lies in Lankuri Bhanjyang of Mahalaxmi Municipality, Lalitpur, Nepal. Although he was popular all over the south Asia in that era (Badal, 2018). When a soul finally returns to Brahma, it is there for an eternity of contentment and ecstasy (Nandan \& Jangubhai, The Comparative study between Hinduism and Buddhism, 2013). But Buddhism is based on the philosophy of impermanence, no self, and suffering. The Baudha stupa is made by the relic of the same Kassap 
Buddha but he was borne in Varanasi and lived 40 thousand years.

One central belief of Buddhism is referred to as reincarnation - the concept that people are reborn after dying. In fact, most individuals go through many cycles of birth, living, death and rebirth. A practicing Buddhist differentiates between the concepts of rebirth and reincarnation. In reincarnation, the individual may recur repeatedly. In rebirth, a person does not necessarily return to Earth as the same entity ever again (Saisuta, 2012). He compares it to a leaf growing on a tree. When the withering leaf falls off, a new leaf will eventually replace it. It is similar to the old leaf, but it is not identical to the original leaf. Buddhism is a philosophy of life expounded by Gautama Buddha ("Buddha" means "enlightened one"), who lived and taught in Nepal and northern India in the 6th century B.C. The Buddha was not a god and the philosophy of Buddhism does not entail any theistic world view. The teachings of the Buddha are aimed solely at liberating emotional beings from suffering (Saisuta, 2012). There used to be 1000 Buddhas in the Vyuha Kalpalinage of Buddhists.

Min Bahadur Shakya in his paper remarks, today Boudha- Kathmandu has become a remarkable center for Dharma Practice. After 1959, with the influx of high Lamas from Tibet all the Tibetan Buddhist traditions have built substantial monasteries around the stupa. Every day the Stupa is visited by hundreds of pilgrims, and the Tibetan community in exile in the Kathmandu valley has made Boudha the Vatican of Tibetan Buddhism in Nepal. The fifth and sixth centuries B. C. were a period in which numerous new religious orders were created to challenge the orthodoxy of Vedic Brahmanism. Along with Buddhism, other new religious orders included the Jains, Ajivikas, and Charvakas, while Vedic Brahmanism slowly transformed into the ancestral forms of modern Hinduism. However, Buddhism is supreme.

\section{Objectives and Methodology}

The main objective of the study is to analyze the historical importance of Boudhanath Stupa and Kassap Buddha. Comparative Historical Analysis (CHA) method has been applied to analyze the collected facts and information. Comparative Historical Analysis is a method of research to analyze the historical evidences with the comparison of next story or events.

\section{Baudha Stupa Kathmandu}

The stupa has an interesting history of its own which explains this strange name. It is said in this story that Kassapa was a Buddha that lived a long time before Shakyamuni Buḍdha. after Kassapa Buddha's demise, a certain old Woman-Ma-jha-zi-ma (ma bya rzi ma) who owned 
hens farm, with her four sons, interred this great sage's remains at the spot over which the great mound now stands, the latter having been built by the woman herself. Before starting on the work of construction, she petitioned the King of the time to grand a land size of a piece of skin and obtained permission to "proceed with" building a tower. The king was surprised how she going to build it on such small size of land, and gave her both land and permission. She then carefully cut the skin and made skin-rope (lung) and circulate the area. Which become the size of present area of Bouddhanath. By the time that, as a result of great sacrifices on the part of the woman and her four sons, the groundwork of the structure had been finished, those who saw it were astonished at the greatness of the scale on which it was undertaken. Especially was this the case with the high officials of the country, who all said that if such a poor old dame were allowed to complete building such a stupendous tower, they themselves would have to dedicate a temple as great as a mountain, and so they decided to ask the King to disallow the further progress of the work. According to Buddhist tradition, he obtained his enlightenment in seven days meditation in Isipatan in, gave his first sermon in Sarnath, and died in Kushinagar (Bhikkhu, 2016).

When the King was approached on the matter his Majesty replied: "I have finished giving the order to the woman to proceed with the work. Kings must not eat their words, and I cannot undo my orders now" which is known as (Kha-Shor), thus, the name came as Jya Lung Khashor. So the tower was allowed to be finished, and hence its unique name, "Jya Lung Kha-shor Chorten Chenpo." I rather think, however, that the tower must have been built after the days of Sakyamuni Buddha, for the above description from Tibetan books is different from the records in Sanskrit, which are more reliable than the Tibetan." the biggest stupa in Nepal. However, Nepalese historians reject this history since it was heard only after Tibetan refugees established themselves in Nepal. the sangha would retreat to monasteries, public parks or forests, where people would come to them (Sujato \& Brahmali, 2013).

Politically, the period between 500B.C. and 500 A.D. was characterized by periods of greater and lesser centralized control. Chandragupta Maurya founded the earliest large empire in South Asia in c. 320 b.c. in the Gangetic Plain. At its greatest extent, the Mauryan Empire controlled all but the most southern portions of mainland South Asia, though imperial control was likely weak in the peripheries. Chandragupta's grandson, Asoka, ruled the Mauryan Empire from 273-232 b.c. Asoka is mostly known through inscriptions he had carved across the subcontinent and Buddhist textual accounts from Sri Lanka. Asoka is portrayed as a great hero-king of Buddhism, actively supporting and promoting Buddhism across his empire (Fogelin, 2014). Asoka's inscriptions, however, present a more nuanced picture of his relationship with Buddhism. In his inscriptions he propounds a more generic form of religiosity that, while concordant with Buddhist tenets, 
appealed to the full range of religious orders found throughout the empire. After Asoka, the Mauryan Empire gradually diminished in power, with the final Mauryan king assassinated in 185 b.c. Following the collapse of the Mauryan Empire, numerous successor states emerged across South Asia. In the Gangetic Plains, the Mauryan Empire was followed by a succession of states, including the Sungas (185-73 b.c.) and eventually the Guptas (c. a.d. 320-550).

In short, Indian Buddhists of the sixth century came to be more concerned with inter-religious conflicts rather than intra-religious contentions (Ham, 2016). According to the Theravada tradition, the seven Buddhas named in the early Buddhist texts are said to be of the following number in the specified Kalpa, bridging the Vyuhakalpa and the Bhadrakalpa:

Vipassi Buddha (the 998th Buddha of the Vyuhakalpa), Sikhi Buddha (the 999th Buddha of the Vyuhakalpa), Vessabhu Buddha (the 1000th and final Buddha of the Vyuhakalpa), Kakusandha Buddha (the first Buddha of the Bhadrakalpa), Konagamana Buddha (the second Buddha of the Bhadrakalpa), Kassapa Buddha (the third Buddha of the Bhadrakalpa), Gautama Buddha (the fourth and present Buddha of the Bhadrakalpa), Maitteya Buddha (the fifth and upcoming future Buddha) (Bhikkhu, 2016)

Among these Buddhas Boudha Stupa is made by the relics of Kassapa Buddha - the third Buddha of this Bhadra Kalpa.

\section{Nalanika Jatak Katha}

In Nalinika Jataka (Ja 526), a famous Jatak story of Buddhists Philosophy, a sage live alone in the hills of Gandhamandan. Once his semen passes through the urine while bathing in the Kathmandu lake and a deer drank the water and get pregnant. A human boy is later born to the deer and he is brought up in complete seclusion from mankind, and most importantly, from womankind. The boy's ascetic power becomes so great that Sakka (the Buddhist Indra) in his heaven is worried by it and causes a drought to occur in the country and blames it on the boy. He then convinces the King to send his daughter to seduce him and to break his power. The King and his daughter accept Sakka's reasoning and in good faith - and for the benefit of the country - agree to the plot.

The girl dresses up as an ascetic and while the father (the Bodhisatta-Bhiwandak) is away gathering roots and fruits in the forest, she manages to seduce the boy, who has never seen a woman before. Through their reveling, the boy does indeed lose his powers, the girl then leaves. When his father returns, the boy, who has become infatuated with his new friend, tells him all about it, only to be instructed and rebuked by his father, and repent his actions. This is not the 
only story of Isisinga that appears in the Jatakas. There is another, and somewhat similar, story just a few pages before, and which is referred to in this story.

That is Jataka 523, the Alambusajataka, but there Sakka chooses a heavenly nymph to seduce the ascetic. The outcome is the same, the sage is seduced, repents and Sakka is thwarted, but some reason he does not seem upset. In fact, he grants a boon to the seductress. The story also appears in the Mahavastu, but Ekasringa, as he is known there, is the Bodhisattva, and Nalini is Yasodhara in an earlier existence. There is a variation in the story as without his knowing it, Ekasringa is married to the girl and has to take up his responsibilities, eventually becoming the King and having 32 children, before he retires once again to the forest and regains his former powers. The Grandfather of Ekshringa or father of Vibhandak is known as Kasyap. The sage was a grandson of Kassap Buddha -the previous life of Gautam Buddha. The birthplace of Ekshring Bodhisattwa is in Mahalaxmi Municipality of Shringarishi Aashram.

\section{Kassap Buddha}

Kassapa Buddha (Pali), known as Kasyapa in Sanskrit, is one of the ancient Buddhas whose biography is chronicled in chapter 24 of the Buddhavamsa, one of the books of the Pali Canon. According to Theravada Buddhist tradition, Kassapa is the twenty-seventh of the twenty-nine named Buddhas, the sixth of the Seven Buddhas of Antiquity, and the third of the five Buddhas of the present Kalpa. The present Kalpa is called a Mahabhadrakalpa (great auspicious aeon). The five Buddhas of the present Kalpa are: Kakusandha (the first Buddha of the Bhadrakalpa), Konagamana (the second Buddha of the Bhadrakalpa), Kassapa (the third Buddha of the Bhadrakalpa), Gautama (the fourth and present Buddha of the Bhadrakalpa), Maitreya (the fifth and future Buddha of the Bhadrakalpa).

Sage Kassapa was born in Isipatana Deer Park. This place is located in Varanasi, a city in the modern-day state of Uttar Pradesh in northern India. His parents were the Brahmins Brahmadatta and Dhanavati, of the Kashyap Gotra in chapter 24 of the Buddhavamsa. believe in the existence of gods or deities on different planes (Nandan \& Jangubhai, The Comparative study between Hinduism and Buddhism, 2013). Kassap was born in Baranasi, he had visited Nepal and settled in meditation in Lankuri Bhanjyang.

According to legend, his body was twenty cubits high, and he lived for two thousand years in three different palaces. They are Hamsa, Yasa, and Sirinanda. His chief wife was Sunanda, who bore him a son named Vijitasena. Kassapa gave up his worldly life traveling in his palace. He practiced austerities for only seven days. Just before attaining enlightenment, he accepted a meal 
of milk-rice from his wife and grass for his seat from a yavapalaka named Soma. His Bodhi tree (the tree under which he attained enlightenment) was a banyan, and he preached his first sermon at Isipatana to an assembly of monks who had renounced the world in his company also mentioned in Buddhabamsa.

According to the story, Kassapa performed the Twin Miracle at the foot of an asana tree outside Sundar Nagar. He held only one assembly of his disciples; among his most famous conversions was that of Naradeva, a Yaksha. His chief disciples among monks were Tissa and Bharadvaja, and among nuns were Anula and Uruvela, his constant attendant being Sabbamitta. Among his patrons, the most eminent were Sumangala and Ghattikara, Vijitasena, and Bhadda. Kassapa died at the age of forty thousand years, in the city of Kashi, in the Kashi Kingdom (now known as Varanasi, in the modern-day Indian state of Uttar Pradesh). Over his relics was raised a stupa one league in height, each brick of which was worth one crore (ten million) rupees. (Sujato \& Brahmali, 2013)

There was initially a great difference of opinion on what should be the size of the stupa and of what material it should be built. Construction of the stupa was begun after these issues were finally settled. But then the citizens found they lacked sufficient funds to complete the stupa. An anagami devotee named Sorata travelled throughout Asia, requesting money from the people for the completion of the stupa. He sent the money as he received it, and on hearing that the work was completed, he set out to go and worship the stupa. However, he was seized by robbers and murdered in the forest, which later came to be known as the Andhavana. At the same stupa, Anuruddha, who was then a householder in Varanasi, offered butter and molasses in brass bowls, which were placed without any interval around the stupa.

Boudhanath is also called the Khasa Chaitya, and in Nepal Bhasa it is called Khasti, similarly in Standard Tibetan it is called Jarung Khashor, is a stupa in Kathmandu, Nepal. The stupa's massive mandala makes it one of the largest spherical stupas in Nepal. The Buddhist stupa of Boudha Stupa dominates the skyline; it is one of the largest unique structure's stupas in the world. The influx of large populations of refugees from Tibet has seen the construction of over 50 gompas (Tibetan convent) around Boudha. As of 1979, Boudha Stupa is a UNESCO World Heritage Site (Badal, 2018).

The Stupa is on the ancient trade route from Tibet which enters the Kathmandu Valley by the village of Sankhu in the northeast corner, passes by Boudha Stupa to the ancient and smaller stupa Charumati. It then turns directly south, heading over the Bagmati River to Lalitpur - thus 
bypassing the main city of Kathmandu (which was a later foundation). Tibetan merchants have rested and offered prayers here for many centuries. When refugees entered Nepal from Tibet in the 1950s, many decided to live around Boudhanath. The Stupa is said to entomb the remains of Kassapa Buddha.

The Gopalaraja Vamsavali says Boudhanath was founded by the Nepalese Licchavi king Shivadeva (590-604 CE); though other Nepalese chronicles date it to the reign of King Manadeva (464-505 CE). Tibetan sources claim a mound on the site was excavated in the late 15th or early 16th century and the bones of King Ampshuvarma 605-621 were discovered there. The earliest historical references to the Khaasti Chaitya are found in the Chronicles of the Newars. Firstly, Khaasti is mentioned as one of the four stupas found by the Licchavi king Vrisadeva (AD 400) or Vikramjit. Secondly, the Newars legend of the stupa's origin attributes it to king Dharmadeva's son, Manadeva as atonement for his un writing parricide Manadeva was the great Licchavi king, military conqueror and the patron of the arts who reigned AD 464-505. Manadeva is also linked with the Swayambhu Chaitya of Gum Bahal. Thirdly, another great Licchhavi king Shivadeva (AD 590-604) is associated with Boudha by an inscription; he may have restored the chaitya. Buddha is also sometimes translated as "The Enlightened One" (Shakya \& Shakya, 2008).

According to the history of Nepal, the palace of King Vikramjit (Licchavi King) once stood where the Naranhiti Palace currently stands. King Vikramjit instructed that a Hiti should be built in the southern part of palace courtyard, but there was no sign of water from the Hiti, for which the king consulted Astrologers. Astrologers suggested that a sacrifice with a male candidate having 'swee-nita lachhyan', or thirty-two perfections should be performed. Only the king himself and his two princes were suitable candidates. So, the king decided to sacrifice himself and ordered one of his sons to sacrifice him so that sign of water could be seen at the Hiti. The king told his son that a man will be sleeping by covering his face and body, and to sacrifice him without looking at his face. After the son did so, he realized he had killed his own father. With regret and guilty he consulted with priests for way to salvation. The priests suggested him to fly a 'bwo-khaa' a flying hen from the top of Mhaasu Khwaa Maju. The hen landed in the place where the chaitya is currently standing. An Ajimaa was already located at that place before the chaitya construction started. During the time of its construction, the place was struck with a drought and the people managed to abate the scarcity of water by collecting the droplets of dew. Dew is called 'Khasu' and droplets are called 'Ti'.

Historians suggest that the traditional knowledge to harvest dew droplets have been lost with time. The places that end with 'Ti' have similar history, such as Chalati, Kusunti, and so on. 
Khaasti Ajimaa is one of the important Ajima of Kathmandu. The Newa tradition consider Ajima as super power. These female energies protect the nation. The tradition of Kumari relates to a place called 'Kumari-gaal' which is south to Khaasti.

However, the emperor Trisong Detsen (755 to 797) of the Tibetan Empire is also traditionally associated with the construction of the Boudhanath Stupa. The Yolmo Shakya Zangpo from Helambu resurrected Boudhanath. Princess of Nepal Bhrikuti married the King of Tibet Songtsen Gampo. His other Chinese wife and Bhrikuti are credited for introduction and spread of Buddhism in Tibet. Along Songtsen Gampo was Trisong Detsen, first Dharma King under him. While Buddhism was spreading in Tibet, and Tibet-Nepal trade relations were being stronger, a widow Tibetan woman travelled from Lhasa to visit Khaasti. She brought her four sons and they were fascinated by witnessing how Newar people constructed chaitya, a meta-symbolic construction with distinct levels of suggestion, sagacity and profoundness. The woman's name was Jyajhima, who took shade for many days in Khaasti. Impressed by the hospitality of Newars, she and her sons went back to Lhasa and told people stories about her experience in Nepal. She is notable as in those times, only traders and specially men were ones traveling Nepal-Tibet and back. She was fascinated by Khaasti, when she heard stories of Bhrikuti spread in Lhasa. Being a widow woman she had to ask permission from the king to visit Khaasti. Jyajhima, a hen rearer woman is noted down by the local Newars of those times because of her attraction to the pilgrimage. It is said that she spends many days with her four sons in the premises of Khaasti before going back to Lhasa.

\section{Conclusion}

Baudha Stupa also belongs to the Nyngmapa sect of Tibetan Buddhism. It is very important stupa of the development of Buddhism in Nepal. It is also related with entire sects like Therawad, Mahayan, Bajrayan and Himalayan Buddhism. For centuries, Boudhanath has been an important place of pilgrimage and meditation for Tibetan Buddhists \& local Nepalese. It is located on what was a major trade route between Nepal and Tibet. Many traveling merchants used it as a resting place. It is also a popular tourist site. In 1979, Boudha became a UNESCO World Heritage Site. The Great Stupa of Boudhanath is the focal point of Kathmandu. The story of Nalanika (Nalanika Jatak Katha) claims that Shringa (Having a horn in head) sage was the grandson of Kassap and son of Vibhandak sages was born in Mahalaxmi municipality, Lankuri Bhanjyang Shringa Rishi Ashram. Therefore, Kassap Buddha had visited and settled few times in the municipality. Thus Baudha Stupa - made by relics of Kassap Budha- Baudha Kathmandu has clear relation with Shringa Rishi Ashram of Lalitpur. 


\section{References}

Badal, B P. "Historical Perspective of Mahalaxmi Municipality: An integrated development prespective." Research Nepal Journal of Development Studies Year 1st Issue 2nd, 2018 November (2018): 20-33.

Bhikkhu, Anandajoti. Beyond the Tipitaka: A Field Guide to Post-canonical Pāli Literature. Nyanatusita: Access to Insight 2003, 2016.

Fogelin, Lars. "Material Practice and the Metamorphosis of a Sign: Early Buddhist Stupas and the Origin of Mahayana Buddhism." Asian Perspectives, Vol. 51, No. 2 (C) 2014 by the University of Hawai Press (2014).

Ham, Hyoung Seok. "Buddhist Critiques of the Veda and Vedic Sacrifice: A Study of Bhāviveka's Mīmāṃsā Chapter of the Madhyamakahṛdayakārikā and Tarkajvālā." 2016.

Nandan, G. B. and Nasir Ahmed Jangubhai. "The Comparative study between Hinduism and Buddhism." International Journal of Humanities and Social Science Invention, www. ijhssi.org Volume 2 Issue 5 May (2013): 27-31.

Saisuta, Phramaha Nopadol. The Buddhists' core value and perspectives for protection challanges: Faith and Protection. Thailand: High Commissioner's Dialogue Faculty of Buddhism, Mahachulalongkorn Uniserity, 2012.

Shakya, Min Bahadur and Miroj Shakya. Towards a Comprehensive Digital Sanskrit Buddhist Canon. Hanoi, Vietnam : Annual Conference and Joint Meetings with ECAI and JVGC, 2008.

Sujato, Bhikkhu and Bhikkhu Brahmali. The Authenticity of the Early Buddhist Texts. Sydny: Australian Association of Buddhist Studies ; Bodhinyana Monastery, 2013 